\title{
Foraminiferal responses to flood events, human activities and sea-level changes in brackish Lake Jinzai, Shimane Prefecture, southwest Japan, in the last 60 years
}

\author{
Ritsuo Nomura*1, a and Barry P. Roser*2
}

\begin{abstract}
We examined the impacts of both sea-level changes and flood events on the foraminiferal assemblages in brackish Lake Jinzai, northeast Shimane Prefecture, southwest Honshu, Japan, over the last 60 years. Sea-level rises that occurred around the coast of Japan in the 1950s and mid-1970s are recognized by increases in the number of foraminiferal individuals per gram of sediment, as represented by the brackish species Ammonia "beccarii" and the coastal species Elphidium excavatum. Sea-level rise after the 1990s was not accompanied by an increase in the number of foraminiferal individuals, indicating that the foraminiferal abundance is not primarily controlled by sea-level changes, but rather by some other factors. Long-term information of annual COD (Chemical Oxygen Demand) changes in brackish water from the 1980s indicates that organic contents are a major factor controlling the foraminiferal abundances. We confirmed that the sea-level rise from the late 1980-90s to the present did not contribute to the foraminiferal abundances, as did those of the 1950 and 1970s.

These foraminiferal species also have responded to flood events in three different ways : (1) A. "beccarii" developed first, and E. excavatum occurred later; (2) only A. "beccarii" occurred; and (3) both species developed together. The foraminifera responded to the short-term events by increase of individual numbers, suggesting enhanced productivity. Accordingly, flood events contribute an increased supply of food resources for foraminifera, as provided by higher organic contents or nutrients.
\end{abstract}

Keywords : sea-level change, flood events, human activities, foraminifera, 20th century, Lake Jinzai

\section{Introduction}

Sea-level rise caused by recent global warming is now recognized as a significant issue for coastal environments, including marine ecological changes (e.g., IPCC, 2007). In particular, lagoon environments are very sensitive to sealevel rise, in response to the interaction of both river and marine waters, coupled with human activity in their borderlands (Center for Global Environmental Research, 2000). Sea levels have been very variable over the last hundred years, showing both long-term and short-term changes (Senjyu et al., 1999 ; Konishi et al., 2004). Nevertheless, our knowledge of the relationships between sea-level rise and coastal biotic ecology remains poor.

Sea-level rises that occurred in the 1940-50s and the 1970s are significant for our understanding of the responses of lagoon organisms to recent sea-level rise. In a study of Lake Nakaumi, southwest Japan, Nomura (2003) showed

Received November 16, 2008. Accepted May 23, 2009.

*1 Foraminiferal Laboratory, Faculty of Education and Research Center for Coastal Lagoon Environments, Shimane University. 1060 Nishikawatsu, Matsue, 690-8504, Japan.

*2 Interdisciplinary Faculty of Science and Engineering, Shimane University. 1060 Nishikawatsu, Matsue, 690-8504, Japan.

*a Corresponding author : nomura@edu.shimane-u.ac.jp 
that the marine forms of foraminifera occurred in the central part of the lake, and that native foraminifera preferring eutrophic water decreased in the 1940-50s, in response to sea level rise. A backward flow of marine water influences the ecology of the lagoon foraminifera. In Lake Obuchinuma, Aomori Prefecture, northern Japan, numbers of individual brackish foraminifera increased in conjunction with increased marine organic matter, itself a response to the sea-level rise that occurred around 1970 off Hachinohe (Nomura et al., 2006). Regional differences around Japan have also been evident from the 1970s, possibly due to changes in the local wind/atmospheric pressure system (Kawabe, 2001 ; Konishi et al., 2004). Foraminiferal assemblages are controlled by the effect of atmospheric pressure changes on the sea level. Majewski and Zajaczkowski (2007) recognized this relationship in sediment cores from the Svalbard fjords in the North Atlantic in the last 50 years. Climatically induced sea-level changes are thus significant in considering environmental variations of both lagoon waters and organisms. Many reports have demonstrated the effectiveness of foraminiferal evidence for reconstructing sea-level changes (Scott and Medioli, 1980 ; Patterson, 1990 ; Williams, 1994 ; Hayward et al., 1999, 2004a ; Culver and Horton,
2005 ; Horton and Edwards, 2006). However, their main focus is on salt marsh foraminifera recording millennial-scale sea-level changes.

Lake Jinzai in Shimane Prefecture is another lake in the San-in district suitable for investigating the long-term relationships between sealevel changes and their effect on the lagoon water/organisms. This lake is situated near Lake Nakaumi, where environmental changes of brackish water in the 20th century have been outlined just before. Study of Lake Jinzai will thus be significant for determining common features of both lakes that may have been caused by sea-level changes. In order to better understand annual to decadal changes of the brackish environment in this water body, we analyzed core sediment from this lake and reconstructed an environmental history of $\sim 60$ years, examining both natural and human impacts.

\section{Recent water character of Lake Jinzai}

Lake Jinzai is located in the west of Izumo City, Shimane Prefecture, and is connected to the Sea of Japan through the $1.6 \mathrm{~km}$ long Sashimi River (Fig. 1). The lake is small, occupying an area of only $1.35 \mathrm{~km}^{2}$, and average water depth is only $1.1 \mathrm{~m}$, with a maximum depth of $1.8 \mathrm{~m}$ in its center. The general geo-

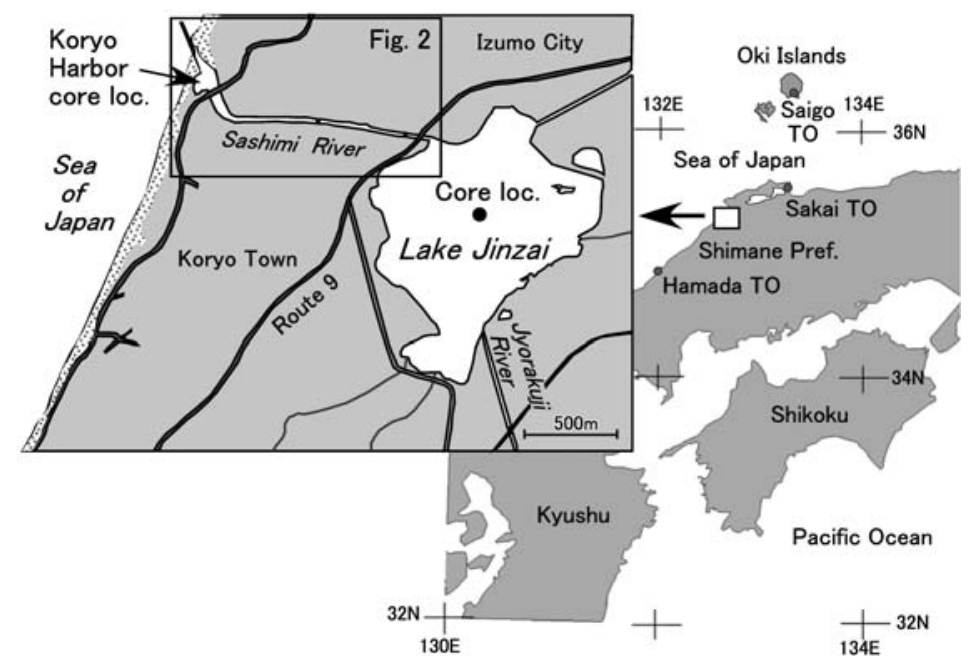

Fig. 1 Map of Lake Jinzai and core sample location Sampling location : $40^{\circ} 57^{\prime} 12.3^{\prime \prime} \mathrm{N} ; 141^{\circ} 21^{\prime} 51.5^{\prime \prime} \mathrm{E} ; 2.2 \mathrm{~m}$ in depth. TO : Tidal Observatory. 
logical, biological and geochemical features of the lake were first described by the Editorial Committee of the Nature of Lake Jinzai (1995). A prefectural observatory has monitored the monthly water character of Lake Jinzai since 1985. According to their observations, the brackish waters of the lake are less saline in its shallow part (average 4,800 $\mathrm{Cl} \mathrm{mg/l)} \mathrm{and} \mathrm{more}$ saline in its deep part (average 6,800 $\mathrm{Cl} \mathrm{mg/l).}$ However, both salinities are very variable throughout the year, above and below a halocline which forms at a depth of $\sim 1 \mathrm{~m}$. The halocline develops in the northern part of the lake, but it disappears temporarily when strong winds blow and/or when heavy rainfall occurs (Hashitani et al., 1995).

\section{Historical background of Lake Jinzai}

\section{Human activity}

Lake Jinzai was originally a fresh-water lake isolated from the Sea of Japan, and formed marshes in the western end of the Izumo Plain. The marsh area flooded when it rained heavily. In order to improve the agricultural productiv- ity of the area, in 1686 A.D., a man-made channel (known as "Sashimi River") was constructed to connect the lake and the Sea of Japan. The lake changed since then from freshwater to brackish (Koryo Town Committee, 2000 ; Yamada et al., 2004).

Human activity in and around the lake intensified after World War II. In 1964, a landslide completely blocked the river channel, and consequently a large-scale flooding occurred. Local government executed several construction works in the river from that time onwards (Fig. 2).

The natural events and human activities around Jinzai area in the 20th century are summarized in Table 1. Flood events were often caused by heavy rainfalls in the rainy season, but those in 1964 and 1972 were the most pronounced.

\section{Sea-level changes}

Sea-level data for this study were available from three tidal observatories recording the long-term sea-level changes in the San-in district, at Sakai, Hamada (Tonoura) and Saigo.

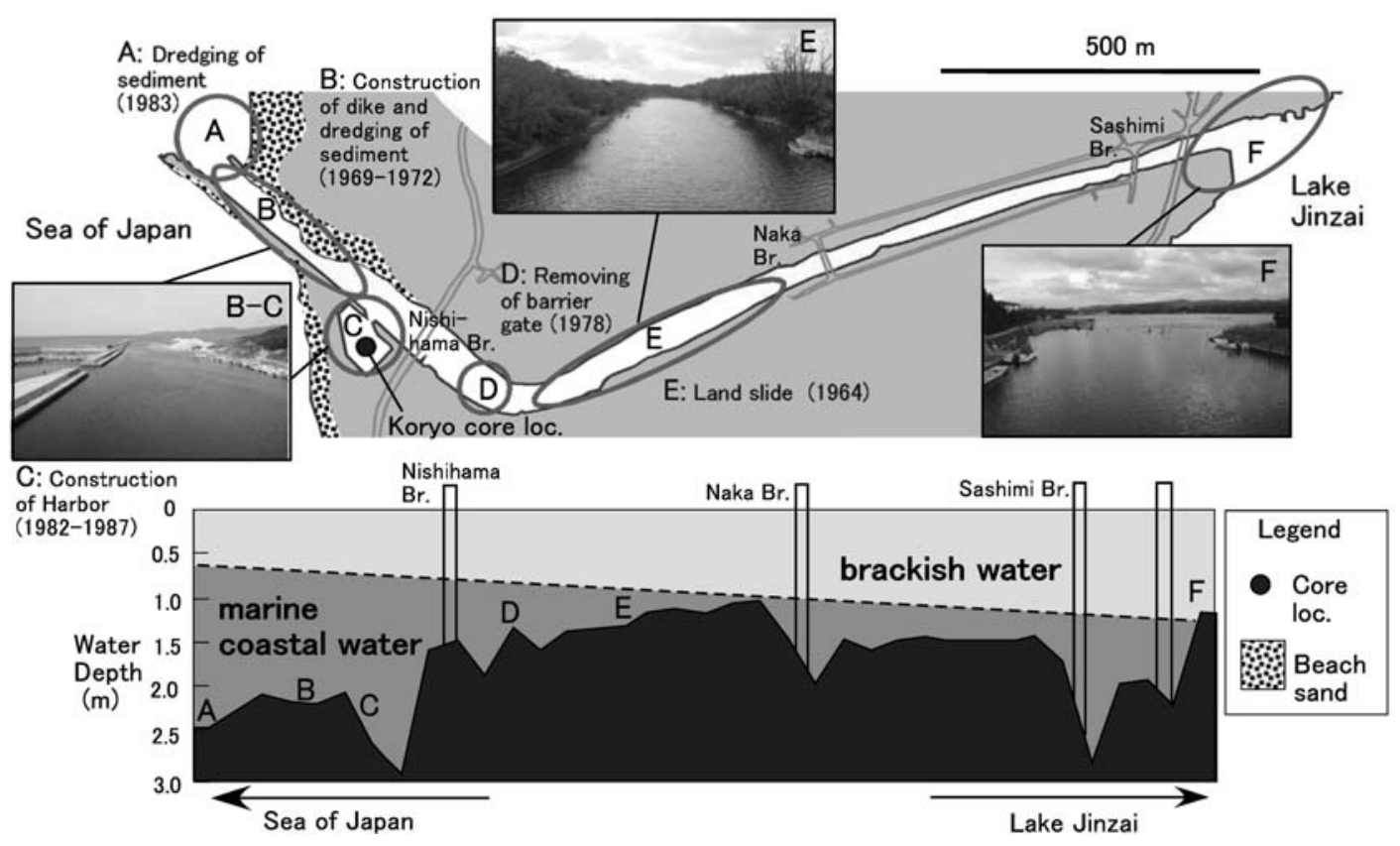

Fig. 2 Profile section of the Sashimi River, and sites of engineering work and embankment failure (indicated by circles)

The water depth information from the Izumo Bureau of Public Works. 
Table 1 Major historical events related to Lake Jinzai (partly from Shimane Prefectural Government, 2004)

\begin{tabular}{|c|c|}
\hline Year & Events \\
\hline 1686 & Excavation work on the Sashimi River \\
\hline 1939 & Drought damage \\
\hline $1943 \cdot 45$ & Typhoons \\
\hline 1951 & Typhoon; heavy rain $(216.8 \mathrm{~mm} /$ day $)$ \\
\hline 1954 & Heavy rain $(280 \mathrm{~mm} /$ day $)$ in the rainy season \\
\hline 1956 & Typhoon and accompanying salt damage \\
\hline 1961 & Heavy rain ( $243 \mathrm{~mm} /$ day) in the rainy season; lake flooding \\
\hline $1964 *$ & $\begin{array}{l}\text { Heavy rain ( } 313 \mathrm{~mm} / \text { day }) \text { and landsliding } \\
\text { in the Sashimi River; lake flooding }\end{array}$ \\
\hline 1964 & Construction of the Sashimi-Ohashi bridge \\
\hline 1965 & Heavy rain $(250 \mathrm{~mm} /$ day $)$ in the rainy season \\
\hline $1969-72$ & $\begin{array}{l}\text { Dike construction and dredging of sediment } \\
\text { in the river mouth }\end{array}$ \\
\hline $1972^{*}$ & Heavy rain $(677 \mathrm{~mm} /$ day $)$ in the rainy season; lake flooding \\
\hline 1972 & Construction of the Naka and Sashimi bridges \\
\hline 1978 & Removal of the Shiodome barrier gate in the Sashimi River \\
\hline $1979-85$ & Dike improvement \\
\hline $1982-87$ & Construction of Koryo Harbor \\
\hline 1983 & Heavy rain ( $330 \mathrm{~mm} /$ day) and lake flooding \\
\hline 1983 & Dredging of sediment in the area of the river mouth \\
\hline 1988 & Heavy rain ( $344 \mathrm{~mm} /$ day) in the rainy season \\
\hline 1990 & Dredging of sediment for ship navigation \\
\hline \multicolumn{2}{|c|}{-present } \\
\hline
\end{tabular}

Annual changes of sea-level observed at Sakai and Hamada (Tonoura) show a similar pattern of variation from the 1950s to the present and are in accordance with the well-known sealevel change around Japan (Japan Meteorological Agency, 2007). Relatively high sea-level positions were recognized in three periods: the late 1940s to early 1950s, the early 1970s, and from 1980 to the present. The sea level in the early 1950s was almost equal to the present level (variation level : $6 \mathrm{~cm}$ ). Sea levels before the 1940s and in the 1960s were lower on average (variation level : $\sim-2 \mathrm{~cm}$ ). Such annual changes of sea level are characteristic of the southwestern coast of Japan. Even in the enclosed brackish Lake Nakaumi, which is near Lake Jinzai, annual water levels responded to these fluctuations of the coastal waters of the Sea of Japan (Nomura, 2003). It is highly likely that the waters of Lake Jinzai were also influenced by variations in the sea level of the Sea of Japan.

The sea-level rise from the latter half of the 1980s onward is well correlated with continuous temperature increases (IPCC, 2007). The best explanation for this is that atmospheric temperature increase recognized in this local area over the last 25 years is related to the global warming (temperature data from Japan Meteorological Agency, 2009) (Nomura et al., 2008). Sea-level changes discussed here were analysed by principal component analysis using the annual data from three tidal observatories near Lake Jinzai, at Hamada (Tonoura), Sakai and Saigo. This extracted the annual variability of sea-level within the second principal component (69\% of the accumulated proportion).

\section{Methods}

We carried out sediment sampling at a water depth of $1.8 \mathrm{~m}$ in central Lake Jinzai in December 2005 , by pushing a $1 \mathrm{~m}$ long and $4 \mathrm{~cm}$ diameter acrylic pipe into the bottom sediment. A pair of cores about $80 \mathrm{~cm}$ long was obtained, to study the foraminiferal occurrences and geo- 
chemical composition respectively. Both cores were sliced at intervals of $1 \mathrm{~cm}$ from top to bottom. One additional core of $35 \mathrm{~cm}$ long (Koryo core) was obtained from the inside of Koryo Harbor near the mouth of the River Sashimi, for the comparative work with the main core from Lake Jinzai. Koryo Harbor was constructed in 1982-1987 (Table 1), and thus this core represents the record of about 20 years.

Wet weights of all samples taken for geochemical analysis were measured before drying at $110^{\circ} \mathrm{C}$ for 12 hours. The samples were then reweighed to determine the water content. The dried samples were subsequently ground and well mixed for organic element analysis using a CHN analyzer (Yanako MT-5). About $3 \mathrm{~g}$ of each powdered sample was pressed into a tablet for X-ray analysis (Horiba XGT5000). The accelerated voltage of $X-$ ray is a 30 $\mathrm{kV}$ and the irradiation diameter was a $100 \mu \mathrm{m}$. The operation time was 600 seconds for a sample. The X-ray intensities (cpm) of each element obtained were expressed as the ratio to the intensity of the uppermost core sample. Radioactivity analyses for ${ }^{210} \mathrm{~Pb}$ and ${ }^{137} \mathrm{Cs}$ were carried out using a well-type system of ultralow background $\gamma$-ray spectrometry (Canberra EGPC150-P16 ; FWHM resolution $1.4 \mathrm{keV}$ at 122 $\mathrm{keV})$. A styrene tube containing $2 \mathrm{~g}$ of wellmixed powdered sediment was used for the radioactivity measurements. The sediments were in radioactive secular equilibrium for ${ }^{222} \mathrm{Rn}$ and its daughters ${ }^{214} \mathrm{~Pb}$ and ${ }^{214} \mathrm{Bi}$ with ${ }^{226} \mathrm{Ra}$, after being sealed in an airtight tube for more than three weeks. All samples analyzed were 1 $\mathrm{cm}$ interval and examined every $2 \mathrm{~cm}$ for $0-47$ $\mathrm{cm}$ in depth and every $4 \mathrm{~cm}$ for $46-69 \mathrm{~cm}$ in depth, except for the interval of $31-34 \mathrm{~cm}$ and $58-61 \mathrm{~cm}$. The $\gamma$-ray counting time was 86,400 seconds.

The measured ${ }^{210} \mathrm{~Pb}$ concentration contains originally existing ${ }^{210} \mathrm{~Pb}$ (= supported ${ }^{210} \mathrm{~Pb}$ ) concentration. Excess ${ }^{210} \mathrm{~Pb}$ is obtained from the measured concentration of ${ }^{210} \mathrm{~Pb}$, by subtracting the concentration of ${ }^{226} \mathrm{Ra}$. The ${ }^{226} \mathrm{Ra}$ concentration is estimated from the measurements of ${ }^{214} \mathrm{~Pb}$ concentration at $352 \mathrm{keV}$.

The foraminiferal analyses followed conventional methods. Sediment samples (15.4-23.0 g in wet weight) were washed on a 250-mesh screen ( $63 \mu \mathrm{m}$ opening size). Samples down to $30 \mathrm{~cm}$ in depth were then stained with rosebengal solution to distinguish live and dead foraminifera. Foraminifera with test sizes $>100$ $\mu \mathrm{m}$ were picked and counted from the washed residues.

\section{Results}

\section{Core description}

The core sediments are composed of dark yellowish-brown clay in the top $2.5 \mathrm{~cm}$, changing to black clay down to a depth of $28 \mathrm{~cm}$. Sediments below this depth consist of dark greenish-gray clay, with intercalated pale gray layer at $28-37 \mathrm{~cm}$. Water content changes from $63 \%$ of the top to $50 \%$ at the base of the core, although there are irregular variations with $\sim 5 \%$ at $10-17 \mathrm{~cm}$ and a distinct decrease below $45 \%$ at $28-37 \mathrm{~cm}$. The latter interval $(28-37 \mathrm{~cm}$ deep) coincides with the occurrence of pale gray sediment, containing fine-grained sand. This interval may represent an influx of allochthonous detritus (possibly of Tertiary origin) derived from landslide deposits.

The Koryo core consists of black sandy clay containing 10-30\% fined-grained sand at 8-33 $\mathrm{cm}$ in depth and clay containing 4-8\% sand at the top to $8 \mathrm{~cm}$ in depth. Water content changes from $69 \%$ of the top to $35 \%$ at the base of soft sediment. The basement of this core $(33-35 \mathrm{~cm}$ deep) consists of pale gray fine-grained sand that characterizes the Pleistocene Sashimi Formation (Kano et al., 1998).

\section{Radioactivity}

Excess ${ }^{210} \mathrm{~Pb}$ and the sedimentation rate: $\mathrm{We}$ applied the constant flux and constant sedimentation rate model (Oldfield and Appleby, 1984) to estimate the sedimentation rate.

$$
C=C(0) e^{-k m / r} ; k=\ln 2 / 22.3 \approx 0.03114 \text { year } / r,
$$

where $C$ is the excess ${ }^{210} \mathrm{~Pb}$ in the sediment sample, $C(0)$ is the initial excess ${ }^{210} \mathrm{~Pb}$ concentration at the sediment-water interface, $r$ is the dry-mass sedimentation rate, and $k$ is the decay constant.

Excess ${ }^{210} \mathrm{~Pb}$, which is produced by ${ }^{222} \mathrm{Rn}$ through dry and/or wet deposition into the water and through the sedimentary processes in the water column, is usually used to obtain the sedimentation rate. 

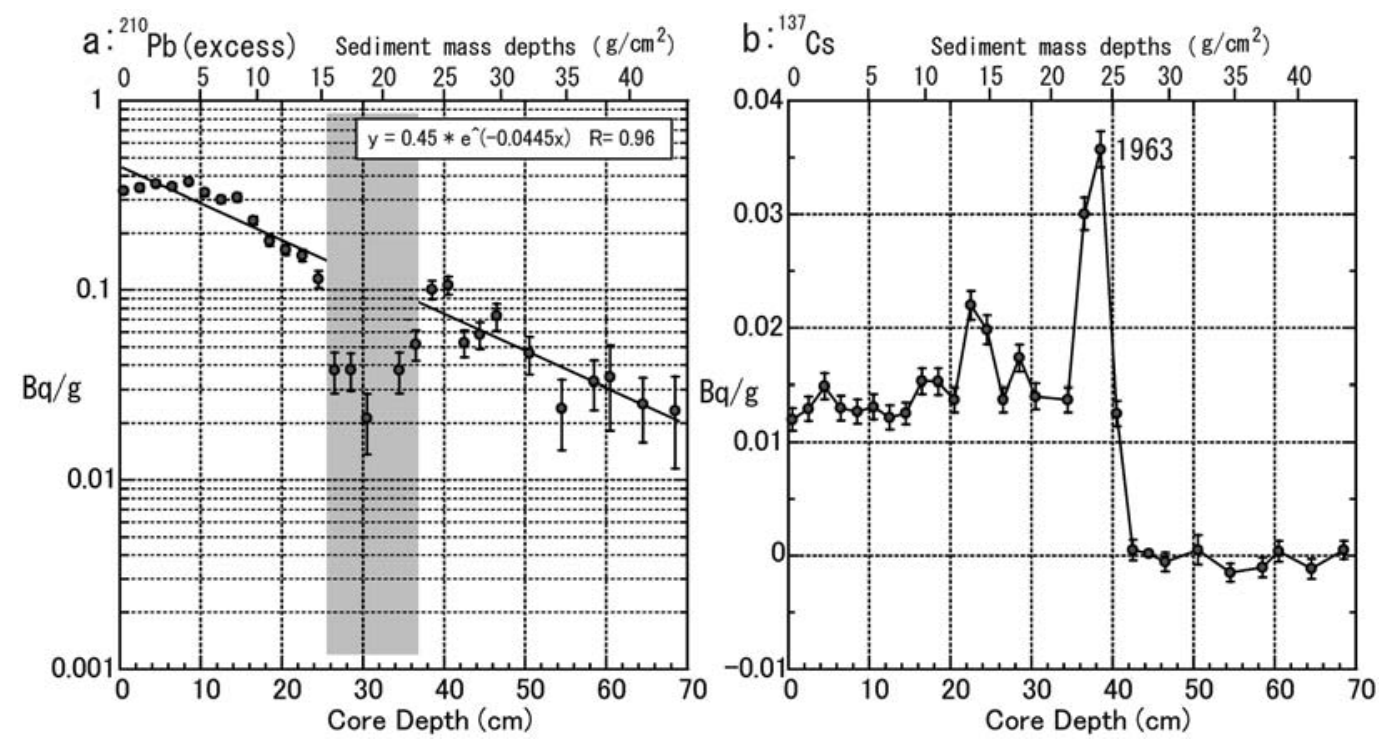

Fig. 3 Distribution of ${ }^{210} \mathrm{~Pb}(\mathrm{~Bq} / \mathrm{g})$ and ${ }^{137} \mathrm{Cs}(\mathrm{Bq} / \mathrm{g})$ to sediment mass depths $\left(\mathrm{g} / \mathrm{cm}^{2}\right)$, respectively, with sigma error bar

Shaded areas indicate major deviations from the overall trend.

Figure $3-\mathrm{a}$ shows the relationships between the excess ${ }^{210} \mathrm{~Pb}$ concentration and mass depths $\left(\mathrm{g} / \mathrm{cm}^{2}\right)$ and core depths $(\mathrm{cm})$ respectively. The results show some samples deviate considerably from the normal decreasing trend. We recognized abnormally low concentrations at $26-37 \mathrm{~cm}$ core depth $\left(=15.23-22.93 \mathrm{~g} / \mathrm{cm}^{2}\right.$ mass depths). This abnormal interval was excluded from the calculations for estimating the sedimentation rate. The sedimentation rate of this core was thus estimated to be $0.698 \mathrm{~cm} /$ year, based on the core depth $\left(0.457 \mathrm{~g} / \mathrm{cm}^{2} /\right.$ year in mass depth).

${ }^{137} \mathrm{Cs}$ and the sedimentation rate: This radionuclide has been detectable in sediments deposited from 1954 onwards, with the greatest release of ${ }^{137} \mathrm{Cs}$ taking place in $1962-1963$ (Krishnaswamy et al., 1971). The most prominent deposition of ${ }^{137} \mathrm{Cs}$ occurred in 1963 (Walling et al., 2002), and this forms a good age marker also in Japan (Kanai and Ikehara, 1995 ; Kanai et al., 1995 ; Igarashi et al., 1996). A clear shift in ${ }^{137} \mathrm{Cs}$ concentration occurs in the interval of $38-43$ $\mathrm{cm}$ from the top of the core (Fig. 3-b). Highest peak ${ }^{137} \mathrm{Cs}$ is found at $38-39 \mathrm{~cm}$ in core depth $\left(=24.15 \mathrm{~g} / \mathrm{cm}^{2}\right)$. If we assign this core depth to 1963 and the $26-37 \mathrm{~cm}$ interval ( $=11 \mathrm{~cm}$ in thick- ness) is regarded as being of flood origin, the sedimentation rate of this core is then 0.655 $\pm 0.012 \mathrm{~cm} /$ year, based on the calculation of core depth (i.e., $\{[38-39 \mathrm{~cm}$ core depth] $-11.0 \mathrm{~cm}\}$ / 42 years). A small broad peak is also found at $22.0-25.0 \mathrm{~cm}$ in core depth. However, this peak is too broad to assign to the fallout event.

The results from ${ }^{210} \mathrm{~Pb}$ and ${ }^{137} \mathrm{Cs}$ yield nearly equal sedimentation rates, and the calculated age differentials between ${ }^{210} \mathrm{~Pb}$ and ${ }^{137} \mathrm{Cs}$ in each sample are small (Table 2). We thus use the age based on the sedimentation rate using coredepth. Our core thus represents a record of $\sim 85$ years back to $1920 \mathrm{AD}$ at the depth of 69 $\mathrm{cm}$, with a maximum error of 13 years.

\section{Foraminifera}

The foraminiferal assemblage in Lake Jinzai is mainly composed of Ammonia "beccarii" and Elphidium excavatum (Fig. 4 and Table 3). These foraminiferal species appeared in the core above $52 \mathrm{~cm}$, suggesting the sediments below this depth were mainly deposited in non-marine or very low salinity brackish environments. Ammonia "beccarii" consistently occurs above 52 $\mathrm{cm}$ with variable numbers of individuals, but there were three distinctive occurrences at core depths of $38-39 \mathrm{~cm}, 20-23 \mathrm{~cm}$ and $13-16 \mathrm{~cm}$, with 
Table 2 Results of radionuclides and calculated ages

\begin{tabular}{|c|c|c|c|c|c|c|c|c|c|c|c|}
\hline $\begin{array}{l}\text { Core } \\
\text { Depth } \\
\text { (cm) }\end{array}$ & $\begin{array}{l}\text { Mid- } \\
\text { depth } \\
(\mathrm{cm})\end{array}$ & $\begin{array}{c}\text { Mass } \\
\text { depth } \\
\left(\mathrm{g} / \mathrm{cm}^{2}\right)\end{array}$ & ${ }^{210} \mathrm{~Pb}$ (exces & s) $(\mathrm{Bq} / \mathrm{g})$ & ${ }^{137} \mathrm{Cs}(\mathrm{Bq}$ & $q / g)$ & $\begin{array}{c}\text { Years BP } \\
{ }^{(210} \mathrm{Pb} \text {-core } \\
\text { depth) }\end{array}$ & $\begin{array}{c}{ }^{210} \mathrm{~Pb} \text {. } \\
\text { based } \\
\text { Age }\end{array}$ & & $\begin{array}{l}\text { error } \\
\text { (year) }\end{array}$ & $\begin{array}{c}\text { Years } \\
\text { BP } \\
\left({ }^{137} \mathrm{Cs} .\right. \\
\text { core } \\
\text { depth })\end{array}$ \\
\hline $0 \cdot 1.0$ & 0.5 & 0.5 & $0.334 \pm$ & 0.013 & $0.012 \pm$ & 0.001 & 0.7 & 2004.5 & \pm & 0.1 & 0.7 \\
\hline $1.0 \cdot 2.0$ & 1.5 & 1.0 & & & & & 2.1 & 2003.1 & \pm & 0.3 & 2.1 \\
\hline $2.0 \cdot 3.0$ & 2.5 & 1.5 & $0.347 \pm$ & 0.017 & $0.013 \pm$ & 0.001 & 3.6 & 2001.7 & \pm & 0.5 & 3.6 \\
\hline $3.0 \cdot 4.0$ & 3.5 & 2.1 & & & & & 5.0 & 2000.2 & \pm & 0.8 & 5.0 \\
\hline $4.0 \cdot 5.0$ & 4.5 & 2.6 & $0.365 \pm$ & 0.013 & $0.015 \pm$ & 0.001 & 6.4 & 1998.8 & \pm & 1.0 & 6.4 \\
\hline $5.0 \cdot 6.0$ & 5.5 & 3.1 & & & & & 7.9 & 1997.4 & \pm & 1.2 & 7.8 \\
\hline $6.0 \cdot 7.0$ & 6.5 & 3.7 & $0.351 \pm$ & 0.014 & $0.013 \pm$ & 0.001 & 9.3 & 1995.9 & \pm & 1.4 & 9.3 \\
\hline $7.0 \cdot 8.0$ & 7.5 & 4.2 & & & & & 10.7 & 1994.5 & \pm & 1.6 & 10.7 \\
\hline $8.0 \cdot 9.0$ & 8.5 & 4.8 & $0.372 \pm$ & 0.013 & $0.013 \pm$ & 0.001 & 12.2 & 1993.1 & \pm & 1.8 & 12.1 \\
\hline $9.0 \cdot 10.0$ & 9.5 & 5.4 & & & & & 13.6 & 1991.6 & \pm & 2.0 & 13.5 \\
\hline $10.0 \cdot 11.0$ & 10.5 & 5.9 & $0.326 \pm$ & 0.013 & $0.013 \pm$ & 0.001 & 15.0 & 1990.2 & \pm & 2.3 & 15.0 \\
\hline $11.0 \cdot 12.0$ & 11.5 & 6.5 & & & & & 16.5 & 1988.8 & \pm & 2.5 & 16.4 \\
\hline $12.0 \cdot 13.0$ & 12.5 & 7.1 & $0.301 \pm$ & 0.013 & $0.012 \pm$ & 0.001 & 17.9 & 1987.3 & \pm & 2.7 & 17.8 \\
\hline $13.0 \cdot 14.0$ & 13.5 & 7.7 & & & & & 19.3 & 1985.9 & \pm & 2.9 & 19.2 \\
\hline $14.0 \cdot 15.0$ & 14.5 & 8.2 & $0.309 \pm$ & 0.016 & $0.013 \pm$ & 0.001 & 20.8 & 1984.5 & \pm & 3.1 & 20.7 \\
\hline $15.0 \cdot 16.0$ & 15.5 & 8.8 & & & & & 22.2 & 1983.0 & \pm & 3.3 & 22.1 \\
\hline $16.0 \cdot 17.0$ & 16.5 & 9.4 & $0.233 \pm$ & 0.012 & $0.015 \pm$ & 0.001 & 23.6 & 1981.6 & \pm & 3.5 & 23.5 \\
\hline $17.0 \cdot 18.0$ & 17.5 & 9.9 & & & & & 25.1 & 1980.2 & \pm & 3.8 & 24.9 \\
\hline $18.0 \cdot 19.0$ & 18.5 & 10.6 & $0.182 \pm$ & 0.011 & $0.015 \pm$ & 0.001 & 26.5 & 1978.7 & \pm & 4.0 & 26.4 \\
\hline $19.0 \cdot 20.0$ & 19.5 & 11.1 & & & & & 27.9 & 1977.3 & \pm & 4.2 & 27.8 \\
\hline $20.0 \cdot 21.0$ & 20.5 & 11.7 & $0.163 \pm$ & 0.011 & $0.014 \pm$ & 0.001 & 29.4 & 1975.9 & \pm & 4.4 & 29.2 \\
\hline $21.0 \cdot 22.0$ & 21.5 & 12.3 & & & & & 30.8 & 1974.4 & \pm & 4.6 & 30.6 \\
\hline $22.0 \cdot 23.0$ & 22.5 & 12.9 & $0.152 \pm$ & 0.011 & $0.022 \pm$ & 0.001 & 32.2 & 1973.0 & \pm & 4.8 & 32.1 \\
\hline $23.0 \cdot 24.0$ & 23.5 & 13.4 & & & & & 33.7 & 1971.6 & \pm & 5.0 & 33.5 \\
\hline $24.0-25.0$ & 24.5 & 14.1 & $0.114 \pm$ & 0.012 & $0.020 \pm$ & 0.001 & 35.1 & 1970.1 & \pm & 5.3 & 34.9 \\
\hline $25.0 \cdot 26.0$ & 25.5 & 14.6 & & & & & 36.5 & 1968.7 & \pm & 5.5 & 36.3 \\
\hline $26.0 \cdot 27.0$ & 26.5 & 15.2 & $0.038 \pm$ & 0.009 & $0.014 \pm$ & 0.001 & 38.0 & 1967.3 & \pm & 5.7 & 37.8 \\
\hline $27.0 \cdot 28.0$ & 27.5 & 15.9 & & & & & 39.4 & 1965.9 & \pm & 5.9 & 39.2 \\
\hline $28.0 \cdot 29.0$ & 28.5 & 16.5 & $0.038 \pm$ & 0.008 & $0.017 \pm$ & 0.001 & & & & & \\
\hline $29.0 \cdot 30.0$ & 29.5 & 17.3 & & & & & & & & & \\
\hline $30.0 \cdot 31.0$ & 30.5 & 18.1 & $0.021 \pm$ & 0.007 & $0.014 \pm$ & 0.001 & & & & & \\
\hline $31.0 \cdot 32.0$ & 31.5 & 18.9 & & & & & & & & & \\
\hline $32.0 \cdot 33.0$ & 32.5 & 19.7 & & & & & & & & & \\
\hline $33.0 \cdot 34.0$ & 33.5 & 20.5 & & & & & & & & & \\
\hline $34.0 \cdot 35.0$ & 34.5 & 21.3 & $0.038 \pm$ & 0.009 & $0.014 \pm$ & 0.001 & & & & & \\
\hline $35.0 \cdot 36.0$ & 35.5 & 22.2 & & & & & & & & & \\
\hline $36.0 \cdot 37.0$ & 36.5 & 22.9 & $0.052 \pm$ & 0.009 & $0.030 \pm$ & 0.001 & & & & & \\
\hline $37.0 \cdot 38.0$ & 37.5 & 23.5 & & & & & 40.8 & 1964.4 & \pm & 6.1 & 40.6 \\
\hline $38.0 \cdot 39.0$ & 38.5 & 24.1 & $0.101 \pm$ & 0.012 & $0.036 \pm$ & 0.002 & 42.3 & 1963.0 & \pm & 6.3 & 42.0 \\
\hline $39.0 * 40.0$ & 39.5 & 24.7 & & & & & 43.7 & 1961.6 & \pm & 6.6 & 43.5 \\
\hline $40.0 * 41.0$ & 40.5 & 25.3 & $0.106 \pm$ & 0.012 & $0.012 \pm$ & 0.001 & 45.1 & 1960.1 & \pm & 6.8 & 44.9 \\
\hline $41.0 \cdot 42.0$ & 41.5 & 25.9 & & & & & 46.6 & 1958.7 & \pm & 7.0 & 46.3 \\
\hline $42.0 \cdot 43.0$ & 42.5 & 26.5 & $0.053 \pm$ & 0.009 & $0.000 \pm$ & 0.001 & 48.0 & 1957.3 & \pm & 7.2 & 47.7 \\
\hline $43.0 \cdot 44.0$ & 43.5 & 27.1 & & & & & 49.4 & 1955.8 & \pm & 7.4 & 49.2 \\
\hline $44.0 \cdot 45.0$ & 44.5 & 27.7 & $0.058 \pm$ & 0.010 & $0.000 \pm$ & 0.000 & 50.9 & 1954.4 & \pm & 7.6 & 50.6 \\
\hline $45.0^{\circ} 46.0$ & 45.5 & 28.3 & & & & & 52.3 & 1953.0 & \pm & 7.8 & 52.0 \\
\hline $46.0 \cdot 47.0$ & 46.5 & 28.9 & $0.073 \pm$ & 0.012 & $(0.001) \pm$ & 0.001 & 53.7 & 1951.5 & \pm & 8.1 & 53.4 \\
\hline $47.0 \cdot 48.0$ & 47.5 & 29.6 & & & & & 55.2 & 1950.1 & \pm & 8.3 & 54.9 \\
\hline $48.0 \cdot 49.0$ & 48.5 & 30.2 & & & & & 56.6 & 1948.7 & \pm & 8.5 & 56.3 \\
\hline $49.0 \cdot 50.0$ & 49.5 & 30.9 & & & & & 58.0 & 1947.2 & \pm & 8.7 & 57.7 \\
\hline $50.0 \cdot 51.0$ & 50.5 & 31.6 & $0.046 \pm$ & 0.011 & $(0.001) \pm$ & 0.001 & 59.5 & 1945.8 & \pm & 8.9 & 59.1 \\
\hline $51.0 \cdot 52.0$ & 51.5 & 32.3 & & & & & 60.9 & 1944.4 & \pm & 9.1 & 60.6 \\
\hline $52.0 \cdot 53.0$ & 52.5 & 33.0 & & & & & 62.3 & 1942.9 & \pm & 9.3 & 62.0 \\
\hline $53.0 \cdot 54.0$ & 53.5 & 33.8 & & & & & 63.8 & 1941.5 & \pm & 9.6 & 63.4 \\
\hline $54.0 \cdot 55.0$ & 54.5 & 34.5 & $0.024 \pm$ & 0.010 & $(0.001) \pm$ & 0.001 & 65.2 & 1940.1 & \pm & 9.8 & 64.8 \\
\hline $55.0 \cdot 56.0$ & 55.5 & 35.2 & & & & & 66.6 & 1938.6 & \pm & 10.0 & 66.3 \\
\hline $56.0 \cdot 57.0$ & 56.5 & 35.9 & & & & & 68.1 & 1937.2 & \pm & 10.2 & 67.7 \\
\hline $57.0 \cdot 58.0$ & 57.5 & 36.6 & & & & & 69.5 & 1935.8 & \pm & 10.4 & 69.1 \\
\hline $58.0 \cdot 59.0$ & 58.5 & 37.4 & $0.033 \pm$ & 0.010 & $(0.001) \pm$ & 0.001 & 70.9 & 1934.3 & \pm & 10.6 & 70.5 \\
\hline $59.0 \cdot 60.0$ & 59.5 & 38.3 & & & & & 72.3 & 1932.9 & \pm & 10.9 & 72.0 \\
\hline $60.0 \cdot 61.0$ & 60.5 & 39.0 & $0.035 \pm$ & 0.016 & $(0.000) \pm$ & 0.001 & 73.8 & 1931.5 & \pm & 11.1 & 73.4 \\
\hline $61.0 \cdot 62.0$ & 61.5 & 39.7 & & & & & 75.2 & 1930.0 & \pm & 11.3 & 74.8 \\
\hline $62.0 \cdot 63.0$ & 62.5 & 40.5 & & & & & 76.6 & 1928.6 & \pm & 11.5 & 76.2 \\
\hline $63.0 \cdot 64.0$ & 63.5 & 41.2 & & & & & 78.1 & 1927.2 & \pm & 11.7 & 77.7 \\
\hline $64.0 \cdot 65.0$ & 64.5 & 41.9 & $0.025 \pm$ & 0.009 & $(0.001) \pm$ & 0.001 & 79.5 & 1925.7 & \pm & 11.9 & 79.1 \\
\hline $65.0 \cdot 66.0$ & 65.5 & 42.6 & & & & & 80.9 & 1924.3 & \pm & 12.1 & 80.5 \\
\hline $66.0 \cdot 67.0$ & 66.5 & 43.4 & & & & & 82.4 & 1922.9 & \pm & 12.4 & 81.9 \\
\hline $67.0 \cdot 68.0$ & 67.5 & 44.1 & & & & & 83.8 & 1921.4 & \pm & 12.6 & 83.4 \\
\hline $68.0 \cdot 69.0$ & 68.5 & 44.8 & $0.023 \pm$ & 0.012 & $0.001 \pm$ & 0.001 & 85.2 & 1920.0 & \pm & 12.8 & 84.8 \\
\hline
\end{tabular}

Cs values in parenthesis are negative. 


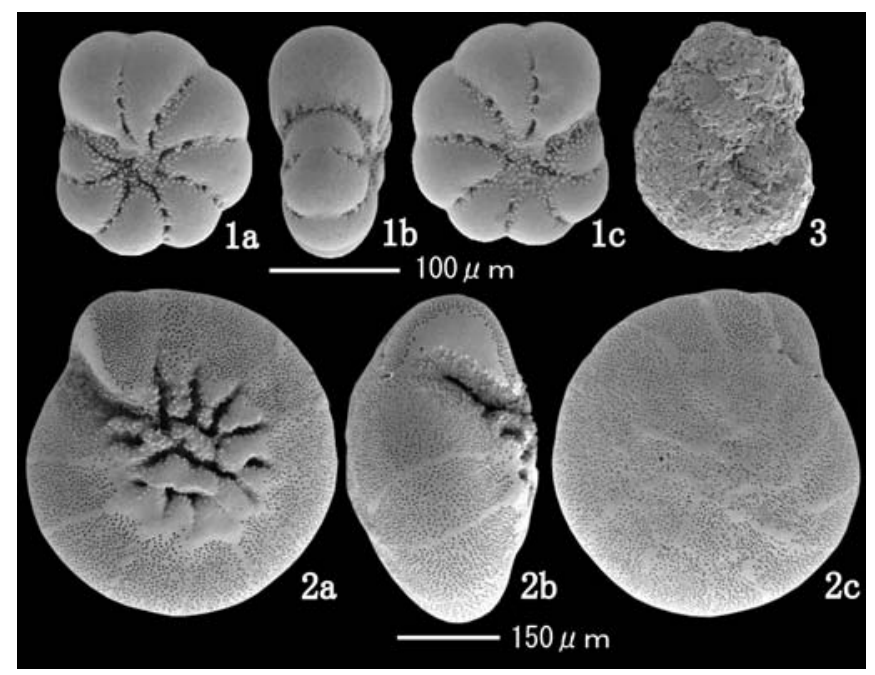

Fig. 4 Major foraminiferal species

(1) Elphidium excavatum, (2) Ammonia "beccarii", and (3) Ammobaculites exiguus.

less prominent occurrences at $6-7 \mathrm{~cm}$ and $46-47$ cm (Fig. 5-a). Elphidium excavatum occurred above $42 \mathrm{~cm}$ in core depth. It is evident, however, that this species occurred mainly at depths of $36-37 \mathrm{~cm}$ and $13-15 \mathrm{~cm}$.

Live forms of $A$. "beccarii" and E. excavatum occurred in the uppermost $11 \mathrm{~cm}$ but numbers of individuals in the total foraminiferal population were very low, accounting for only 3 of 11 individuals at the top $(0-1 \mathrm{~cm}), 2$ of 24 at $6-7 \mathrm{~cm}$ and 2 of 12 at $10-11 \mathrm{~cm}$. The depth preference of these live forms in the sediment cannot be determined.

The foraminiferal assemblage in the harbor at the Sashimi River mouth is dominated by Ammonia "beccarii", Pararotalia nipponica and several miliolid species. However, E. excavatum was not present in the muddy-sand sediments in this core. Ammonia "beccarii" was abundant at a core depth of around $20 \mathrm{~cm}$, but individual numbers of this species decreased to the core top (Fig. 5-b). The epifaunal species P. nippon$i c a$, usually dominant in sandy sediments in coastal areas, increased at around $15 \mathrm{~cm}$ in core depth (Fig. 5-b). Live forms in this core were very few, and numbers were insufficient for assemblage analysis.

\section{Inorganic chemistry}

Major elements including $\mathrm{Al}, \mathrm{K}, \mathrm{Ca}, \mathrm{Mn}$ and Fe clearly show variable $\mathrm{X}$-ray ratios with core depth. Relative $\mathrm{X}$-ray ratios of $\mathrm{Al}, \mathrm{K}, \mathrm{Mn}$ and Fe drop sharply between 10 and $14 \mathrm{~cm}$ in core depth. Between 28-37 cm K, Ca, Mn and S intensity ratios decrease distinctly, whereas that of $\mathrm{Al}$ increased. From $49 \mathrm{~cm}$ to the bottom of the core, the intensity ratio of $\mathrm{S}$ decreased while Fe increased. These inorganic major elements clearly show that abnormal sedimentary processes occurred at different and recent times.

In general $\mathrm{Cl}$ contents gradually decrease toward the bottom of the core (Fig. 6). A plot of the ratio of chlorine intensity and water content $(\mathrm{Cl} /$ water content ratio) shows an exponential downward decline overall, although three deviations from this curve are evident. The intervals at which these deviations occur are strongly correlated with the variations in inorganic element intensities outlined above (Fig. 6). In particular, the interval at $28-37 \mathrm{~cm}$ in depth coincides with the occurrence of pale gray fine-grained sediment.

\section{TOC, $\mathrm{TN}$ and $\mathrm{C} / \mathrm{N}$ ratios}

The distribution of total organic carbon (TOC) and nitrogen (TN) shows a similar pattern of concentration (Fig. 7). Contents of both TOC and TN deviate sharply from the general distribution trends between $27-37 \mathrm{~cm}$ in depth, falling to $<2 \%$ TOC and $0.15 \% \mathrm{TN}$ respectively. In contrast, $\mathrm{TOC} / \mathrm{TN}$ ratios (hereafter $\mathrm{C} / \mathrm{N}$ ra- 
Table 3 Occurrence of foraminifera

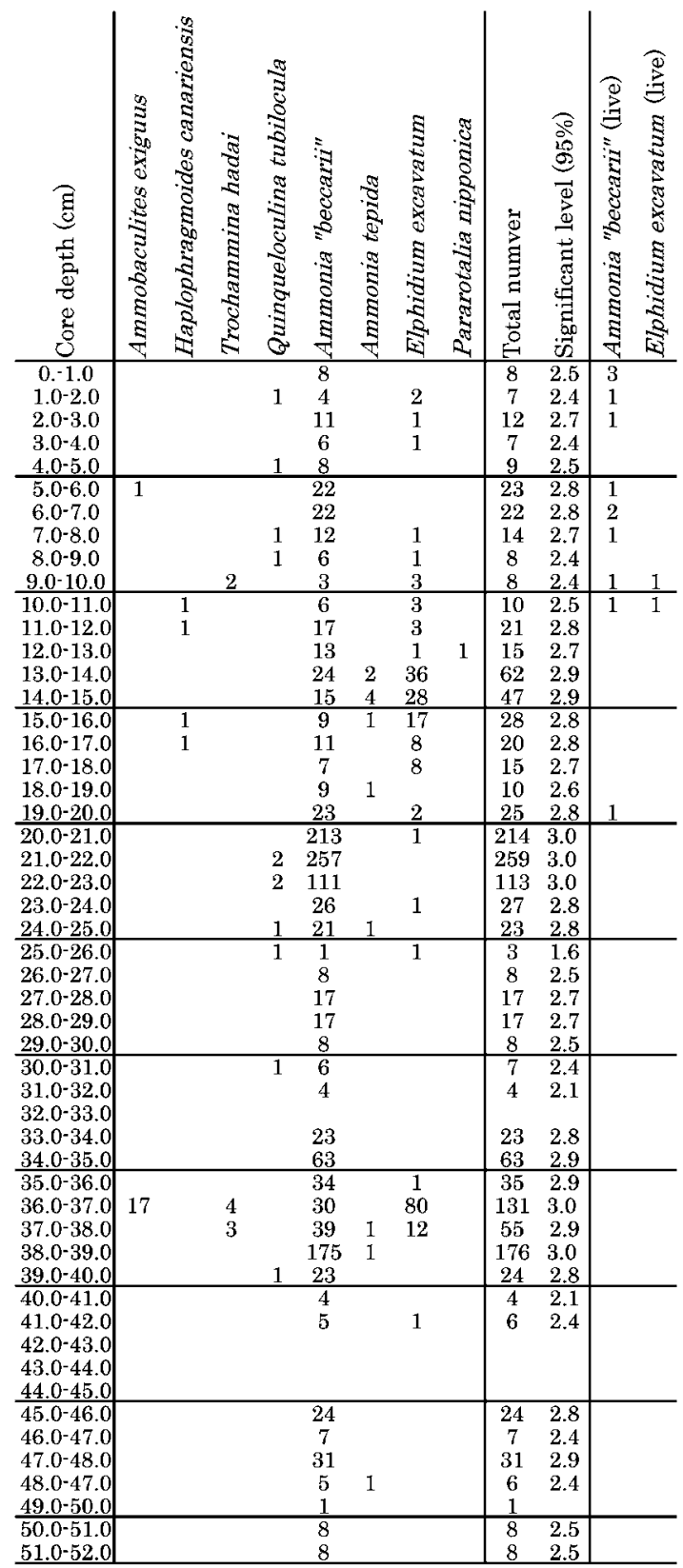

The binominal distribution was applied to test the significant level (95\%) of occurrence in each sample.

tios) rise from $\sim 8$ to $\sim 12$, indicating influx of land-derived organic matter in this interval. Higher plants in terrestrial and near-shore areas have high $\mathrm{C} / \mathrm{N}$ ratios, whereas both phytoand zoo-planktonic organisms have low ratios
(Müller, 1977 ; Sampei and Matsumoto, 2001). Below the horizon of the decreased TOC and $\mathrm{TN}$, both organic elements increase temporarily at $40-41 \mathrm{~cm}$ in core depth, although the $\mathrm{C} / \mathrm{N}$ ratios remain comparable with those prevailing to the base of the core. This indicates that the mix of brackish organisms supplying $\mathrm{C}$ and $\mathrm{N}$ did not change greatly at $40-41 \mathrm{~cm}$, but that productivity was briefly enhanced.

High $\mathrm{C} / \mathrm{N}$ ratio is also recognized in one sample at $11 \mathrm{~cm}$ in core depth, due to decrease in TN content. The lack of change in TOC content in this sample resulted from input of terrestrial organic matter.

\section{Discussion}

\section{Flood events}

Several disasters have been caused by heavy rainfall events in the Jinzai area in the 20th century. Table 1 shows the recent history of disasters and related events. Some of the flood sediments deposited by these events are discussed by Sawai et al. (1998). The Izumo Bureau of Public Works (2004) opened detailed reports of the 1964 and 1972 disasters in the Jinzai area. We identified several layers that record unusual sedimentological and micropaleontological events, at core depths of $10-14 \mathrm{~cm}$, $21-23 \mathrm{~cm}$ and $28-37 \mathrm{~cm}$ (Figs. 5, 6, and 7). Based on the age model, these core depths are correlated with the 1980s, early 1970s and the middle 1960 s respectively. A localized torrential downpour in July, 1964 (289 mm total rainfall : Izumo Bureau of Public Works, 2004) was responsible for the most prominent flood horizon at core depth 28-37 cm (Figs. 6 and 7). This event also caused failure and landsliding of the riverbank in the Sashimi River (Fig. 2). Outflow of the river water was obstructed, and consequently lake water inundated the area around Lake Jinzai. In response to this flood event, the euryhaline species $A$. "beccarii" became prominent, followed later by increased numbers of E. excavatum, which then became major along with A. "beccarii" (Fig. 5-a). Another heavy rainfall event in July, 1972 (524 mm total rainfall : Izumo Bureau of Public Works, 2004), identified at core depth $21-23 \mathrm{~cm}$ (Fig. 5-a), again caused the lake to overflow. This event is not recognized in either the geochemistry or in the sedi- 


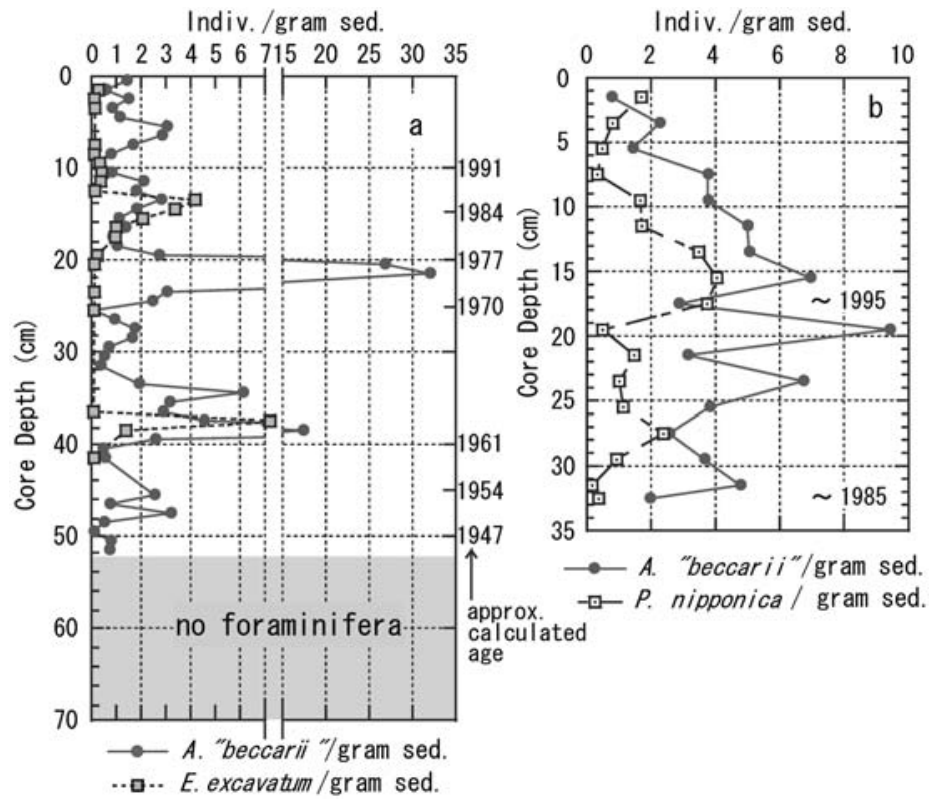

Fig. 5 Occurrences of live and dead foraminiferal species Ammonia "beccarii", Elphidium excavatum, and Pararotalia nipponica

(a) Core from Lake Jinzai. (b) Core from the Sashimi River (Koryo core). Age calibration for the Koryo core assumes the equal sedimentation rate since the harbor constructed in around 1985.

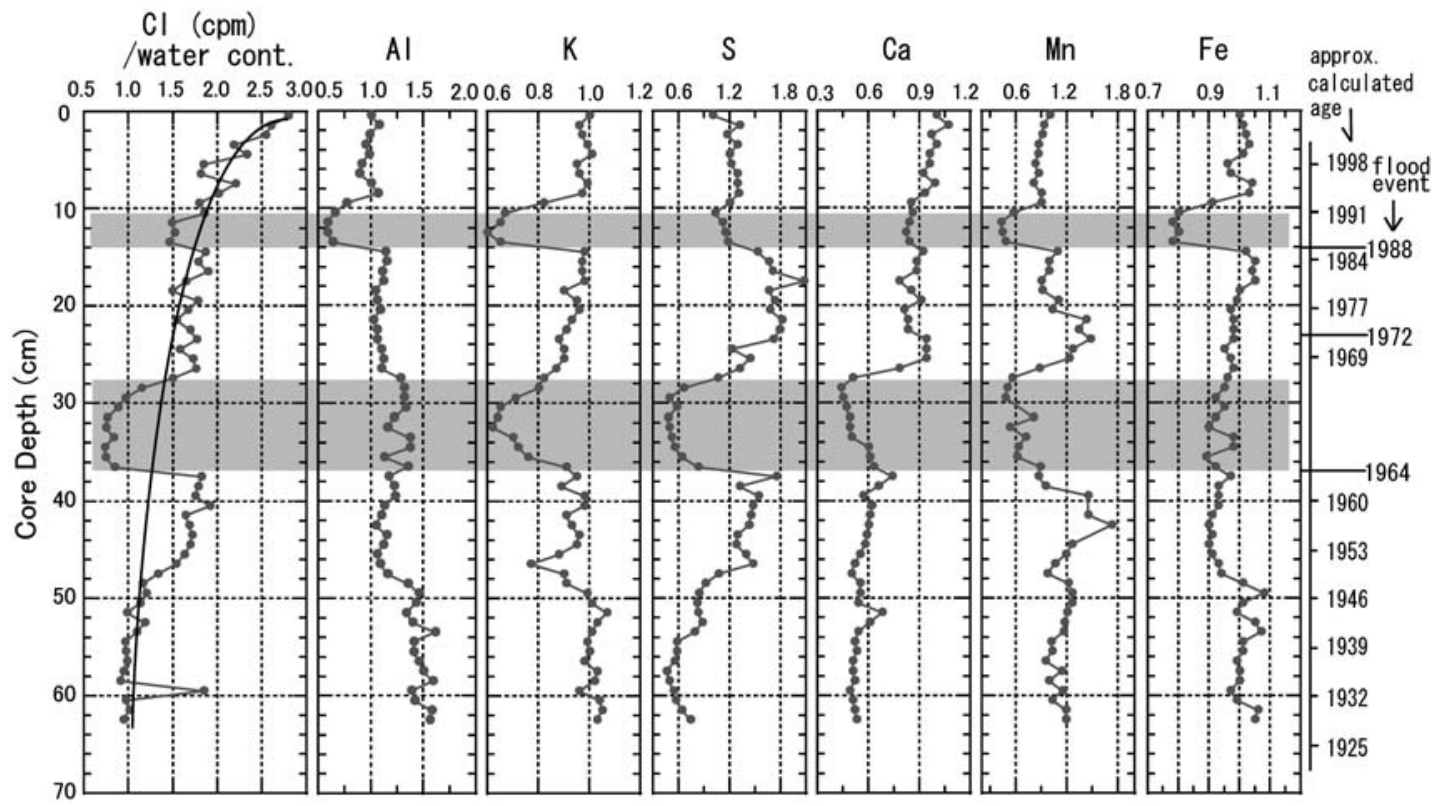

Fig. 6 Depth distribution of Chlorine, Al, K, S, Ca, Mn and Fe intensities to the uppermost sample for each element

Chlorine is depicted as the ratio of $\mathrm{Cl}(\mathrm{cpm})$ to the water content (WC). Shaded areas indicate major deviations from the normal ratios. The curve on the $\mathrm{Cl} / \mathrm{WC}$ plot is interpolated as an exponential curve. 


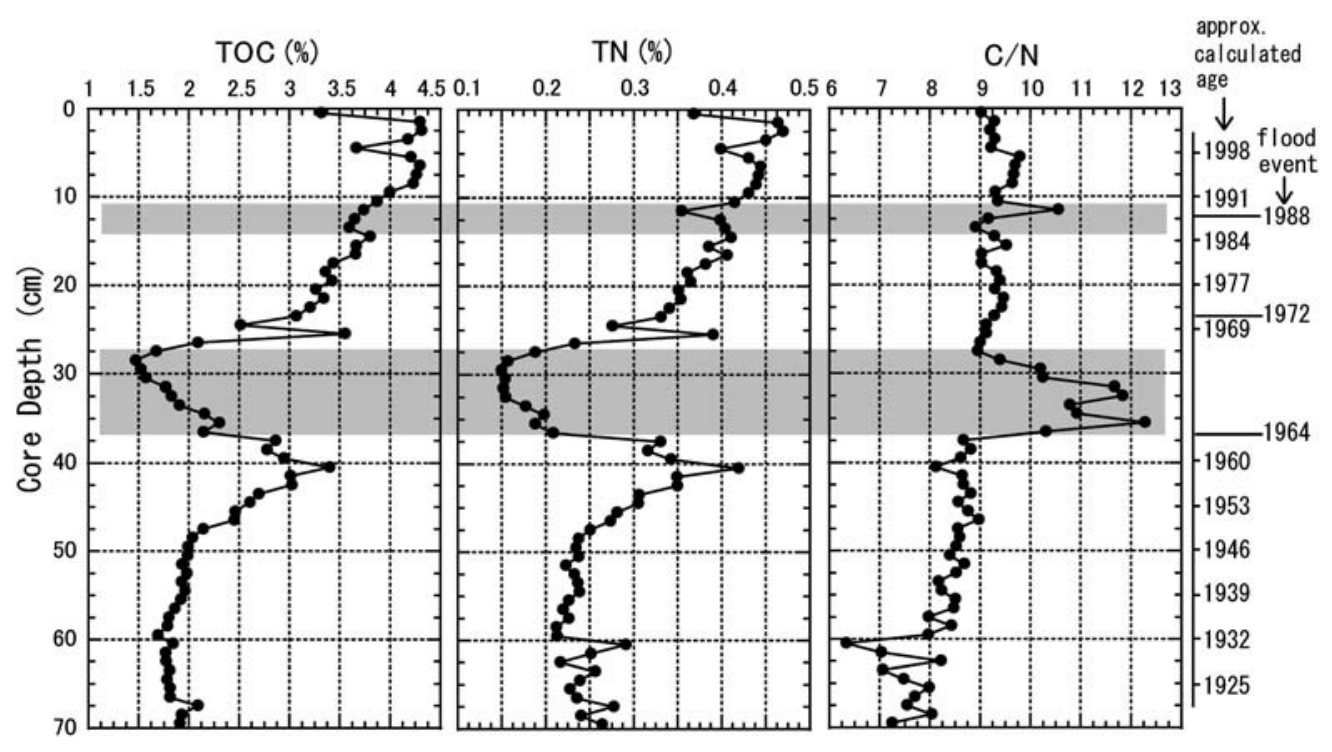

Fig. 7 Relative abundance of total organic carbon (TOC) and total nitrogen (TN), and total organic carbon to total nitrogen ratios $(\mathrm{C} / \mathrm{N})$ in the sediment core

Shaded areas indicate major deviations from the overall trends.

mentary facies, but is reflected by the foraminiferal abundance of $A$. "beccarii" (Fig. 5-a). Other forms such as $E$. excavatum did not respond to this flood event. In response to these events, local government reconfigured the drainage system of Lake Jinzai from 1965 to 1985, in an effort to control the water level (e.g., present highest level $+2.2 \mathrm{~m}$ relative to Tokyo Peil (T.P.)) and to protect its fishery (Shimane Prefectural Government, 2006).

We are also able to identify the flood events that occurred in 1988 at a core depth of 10-14 $\mathrm{cm}$, where major element abundances decrease, similar to the 1964 event, except for aluminum and iron (Fig. 6). Both the inorganic major elements and organic elements reflect these events. The 1988 flood events are marked by foraminiferal abundances of both $A$. "beccarii" and $E$. excavatum in the early stage of the deposits (Fig. 5-a).

2. Foraminiferal response to human activities

The main fishes recorded in fisherman's haul documents in and before 1960 were eels, mullet, crucian carp, carp and Corbicula (Koryo Town Committee, 1970). The present total catch of this fish assemblage has decreased to only onequarter of the 1960s level. Major fish resources have thus changed from the 1960s-1970s onward. This change is believed to be related to human activities such as the re-engineering of the Sashimi River (Table 1) (Izumo City Committee, 1982). The first appearance of Elphidium excavatum is coeval with the change in the fishery. E. excavatum prefers marine waters in estuarine areas (Abbene et al., 2006 ; Vance et al., 2006), and the appearance of this species thus indicates more active upward flow of coastal marine water through the Sashimi River and into the lake. Construction of a dike projecting from the river mouth and dredging of river sediment facilitated the upward flow of marine water. However, these river improvements did not cause abrupt changes in the lake organisms; modification was in fact gradual. A barrier gate previously installed to prevent the active inflow of marine water was removed in 1978 (Fig. 2), but there is no clear-cut evidence of subsequent salinity change in the foraminiferal occurrences (Fig. 8).

Recent environmental changes in estuarine and embayment areas have occurred in multiple ways. Eutrophication as a consequence of human activities and urbanization are major causes of foraminiferal changes (Alve, 1995 ; 


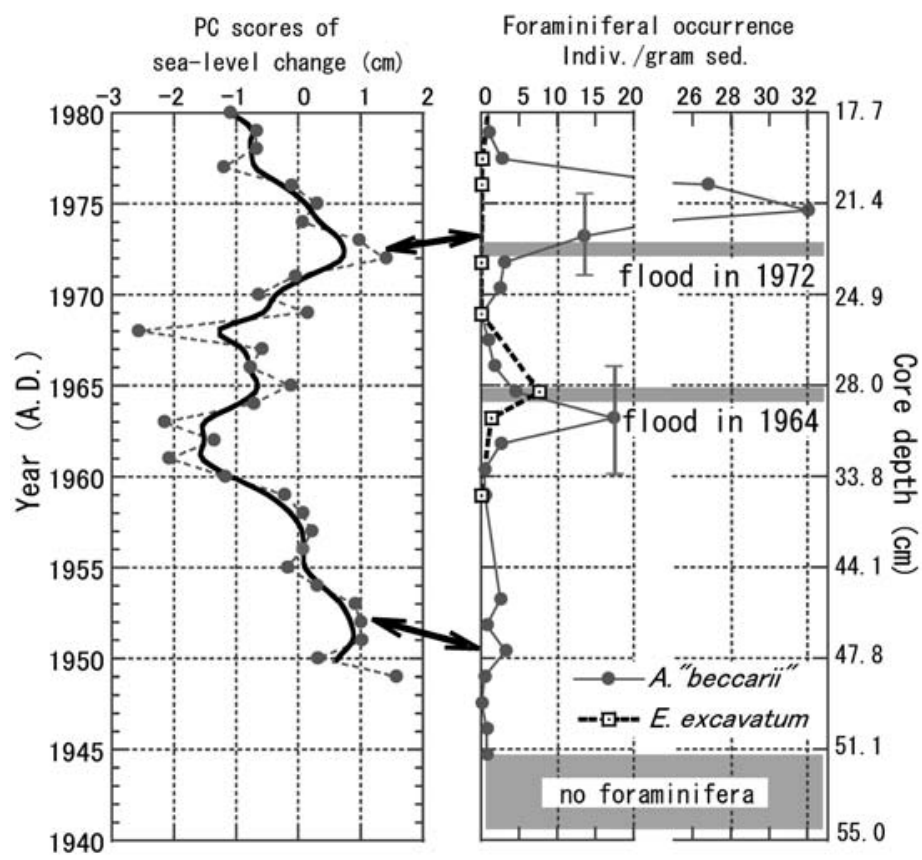

Fig. 8 Stratigraphic distribution of dead Ammonia "beccarii" and Elphidium excavatum from 1945 to 1980 and the correlation with sea-level changes

Flood events occurred at nearly the same time as sea-level rise. Sea-level changes are from the result of Principal Component Analysis ; data from the Japanese Meteorological Agency : Hamada (former Tonoura) Tidal Observatory $\left(40^{\circ} 32^{\prime} \mathrm{N}, 141^{\circ} 32^{\prime} \mathrm{E}\right)$, Sakai TO $\left(40^{\circ} 32^{\prime} \mathrm{N}, 141^{\circ} 32^{\prime} \mathrm{E}\right)$, and Saigo TO $\left(40^{\circ} 32^{\prime} \mathrm{N}, 141^{\circ} 32^{\prime} \mathrm{E}\right)$.

Barmawidjaja et al., 1995 ; Cearreta et al., 2000 ; Thomas et al., 2000 ; Van der Zwaan, 2000 ; Hayward et al., 2004b; Ruiz et al., 2004 ; Platon et al., 2005 ; Tsujimoto et al., 2006a, b, 2008). However, in Lake Jinzai, originally a eutrophic lake, there has been no change in the major components since the first occurrence of foraminifera in $\sim 1950$, although the numbers of individuals have changed episodically.

3. Foraminiferal response to sea-level changes

\section{1) Before the 1950s}

The barren interval from $52 \mathrm{~cm}$ in core depth to the bottom of the core is well correlated with the interval of low sulfur intensities and low $\mathrm{Cl} /$ water content ratios (Figs. 5 and 6). The distribution pattern of these inorganic elements and the absence of foraminifera confirm that the main body of Lake Jinzai was occupied with low saline water prior to the early 1940s. The occurrence of $A$. "beccarii" in the late 1940s suggests the influence of marine water along with the regional sea-level rise that became conspicuous in the 1950s (Japan Meteorological Agency, 2007).

\section{2) The $1950 \mathrm{~s}$ to $1980 \mathrm{~s}$}

Except for the influence of weather events and consequent flooding, the foraminiferal occurrences indicate a number of decadal changes (Fig. 8). Marked increases of foraminiferal numbers are evident in the early to middle 1960s and in the mid-1970s, and these correlate with relatively higher sea-level periods in 1965 and 1972-73. In general, sea-levels around Japan fluctuated, with higher periods in the early 1950s, mid-1970s and mid-1980s to the present, and a lower period in the 1960s (Senjyu et al., 1999 ; Nomura, 2003 ; Konishi et al., 2004). These sea level changes are recognized in the results of principal component analysis (Fig. 8). Both Ammonia "beccarii" and Elphidium excavatum are good indicators for these marked periods of sea-level change. 
The appearance of $A$. "beccarii" in 1952-56 is correlated with the period of higher sea level (Fig. 8). The intimate relationship between the development of the foraminiferal assemblage and sea-level rise suggests the assemblages were influenced by the input of coastal saline water into Lake Jinzai. The ratios of Cl-intensity and water content are coincident with the variation of sulfur intensities in the $38-48 \mathrm{~cm}$ core interval, which is correlated with 1950 1964 (Fig. 6). Increased organic carbon and nitrogen contents are also observed at the same time interval respectively (Fig. 7). Organic carbon and nitrogen ratios $(\mathrm{C} / \mathrm{N}$ ratios) are around 8.3 , suggesting the organic materials are mainly composed of planktonic organisms (Müller, 1977 ; Tyson, 1995 ; Sampei and Matsumoto, 2001). The appearance of $A$. "beccarii" thus indicates an active increase in organic materials in the lake, concomitant with coastal water intrusion into the lake.

Individual numbers of $A$. "beccarii" per gram dry sediment increased just before the flood event in 1964 (Fig. 8). The foraminiferal development at this time is not directly related to the flood event, but both high TOC and TN suggest an increase of organic matter in the lake prior to the flood (Fig. 7). Coeval increase of both chlorine and sulfur contents supports stronger marine influences in this time period (Fig. 6). Increased inflow of saline coastal water must have caused increase in lake productivity just before the flooding. However, we are not sure about this cause, because sealevels in the 1960s were generally positioned at lower levels.

A. "beccarii" persisted in the 1964 flood layer, but its rare occurrences may have been caused by the high sedimentation rate. Otherwise, high input of nutrients during the flooding was sufficient to promote increased phytoplankton productivity, providing the temporary prosperity of E. excavatum. Deep-sea studies have shown that benthic foraminiferal activities are well correlated with the supply of organic matter as a food resource into the bottom water (Gooday, 1993 ; Ohga and Kitazato, 1997). Such a condition of enhanced food supply would be highly likely. In contrast to this consideration, however, both TOC and TN decreased in this flood layer (Fig. 7). C/N ratios (11-12) increased with input of land-derived organic matter into the lake sediments. This is reasonable to consider that a large volume of sediment accumulated within a very short time interval. The very low radioactivities at $26-37 \mathrm{~cm}$ in core depth (Fig. 3-a) indicate that the sediment in this $11 \mathrm{~cm}$-long interval was not a product of normal sedimentary processes in the lake, but suggest land-derived sediment, as indicated by high $\mathrm{C} / \mathrm{N}$ ratio. Thus, we are of opinion that phytoplanktonic organic matter produced in the lake was diluted by flood-derived sediments.

The prominent occurrence of $A$. "beccarii" at $21-23 \mathrm{~cm}$ in core depth, although not accompanied by E. excavatum, is correlated with the higher sea-level position in 1972-1974 (Fig. 8). The occurrence of Ammonia "beccarii" at this time is the highest in the core. However, no clear correlations with inorganic and organic materials are seen at this time in Figures 5 to 7. Another large flood occurred in this area in 1972, coinciding with the period of sea-level rise. According to our age model, the peak occurrence of $A$. "beccarii" was at $1974.4 \pm 4.8$, but it started in 1973. Considering that all the foraminiferal tests are well preserved and that there is no evidence of reworked specimens, this assemblage must be original. We infer that both the 1972-1974 sea-level rise and the flooding influenced the Ammonia assemblage, but the flooding may have been a major impact on this assemblage, because of no occurrence of E. excavatum preferring more saline water is noted.

\section{3) The $1980 \mathrm{~s}$ to 2005}

Annual variation in the water quality of Lake Jinzai has been recorded by the local government from the late 1970s onward (Shimane Prefectural Government, 2005). The lake water is well oxidized throughout the year, except in the deepest part during early summer. The chemical oxygen demand (COD) of the lake falls within the range of $6-8 \mathrm{mg} / 1$, which are values typical of fertilized lagoons in Japan. Figure 9 shows the time-series changes of $A$. "beccarii" and E. excavatum with reference to the 25-year record of COD values of the upper (1 $\mathrm{m}$ depth) and bottom water. Sea-level changes 


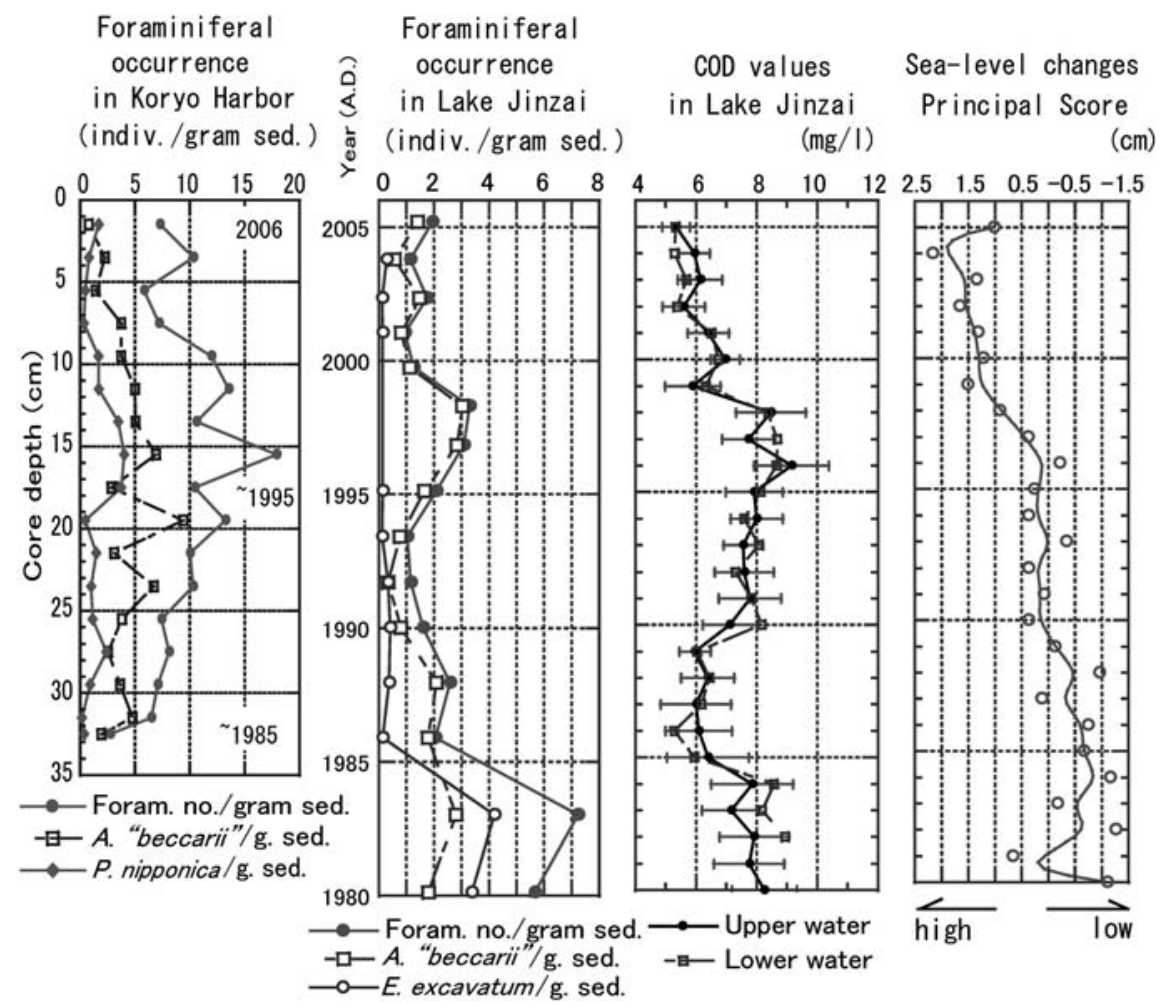

Fig. 9 Stratigraphic distribution of dead Ammonia "beccarii", Elphidium excavatum, and Pararotalia nipponica

Cores are from Lake Jinzai and from Koryo Harbor, near the mouth of the Sashimi River. Annual variations of COD and sea levels from 1980 to 2005 are also shown. COD data from Shimane Prefectural Government (2005).

from 1980 to 2005 are also shown. A clear correlation between the foraminiferal assemblage and the COD variation of the lake is evident, indicating both $A$. "beccarii" and $E$. excavatum are influenced by the fertility of the lake. When the COD values of the both water increased in the early to middle 1990s, foraminiferal occurrences also increased (Fig. 9). Conversely, when the COD values of the bottom water decreased from 1995 onward, the foraminiferal assemblages also tends to decline. Furthermore, this clear relationship can be recognized in the assemblage from the core in Koryo Harbor at the river mouth, where the foraminiferal assemblage is not only characterized by A. "beccarii", but also by the epifaunal form Pararotalia nipponica. Koryo Harbor was constructed in 1982-1987, and if we assigned the bottom of this core to be around 1985, the fo- raminiferal individuals per gram of sediment increased around 1995, coinciding with peak COD and development of the foraminiferal assemblage in Lake Jinzai.

The foraminiferal assemblages of Lake Jinzai and the Sashimi River were thus both influenced in the same manner by water fertility. Sea-level off the San-in district has increased from the mid-1990s and continues to do so today. Comparing the COD values (namely water fertility) with the sea-level changes, the values have decreased and recent trend of the distribution is contrast to the sea-level rise. This opposite distribution trend strongly suggests that the water movement and inflow of coastal water along with the recent sea-level rise acts to reduce the fertility loadings in the lake. However, the recent sea-level rise produces different environmental influences, if we ac- 
cept the interpretation that the sea-level rise before the 1990s enhanced the basic productivity of Lake Jinzai. It is highly probable, taking the foraminiferal evidence into consideration, that the mechanisms of this recent sea-level rise are not the same as those of the 1950-60s and the 1970s. A similar conclusion has been obtained in Kumihama Bay (Nomura et al., 2008). We confirmed that the brackish environment in Lake Jinzai has greatly changed as a result of multiple responses to not only human activities, but also other factors such as sealevel changes and climatically induced flooding.

\section{Conclusions}

A sediment core from Lake Jinzai was studied to clarify the foraminiferal response to sealevel changes over the last 60 years. A simple ${ }^{210} \mathrm{~Pb}$ age model was applied to calibrate the sediments. Except for the flood deposits within which radioactivities deviated from exponential distribution, the sedimentation rate was $0.698 \mathrm{~cm} /$ year. This was confirmed by the ${ }^{137} \mathrm{Cs}$ distribution model, which indicated 0.655 $\pm 0.012 \mathrm{~cm} /$ year. Based on these age models, we determined the sea level impacts on the foraminiferal assemblage. Foraminifera were also influenced by extreme weather events and consequent flooding. The results show :

1. Sea-level rises that occurred in the San-in area in the late 1950s and the mid-1970s can be recognized by increased numbers of foraminifera per gram of sediment, as represented by the typical brackish species Ammonia "beccarii" and euryhaline species Elphidium excavatum.

2. A. "beccarii" occurred in the core above about $50 \mathrm{~cm}$ deep dated at around 1945. The water of Lake Jinzai was low salinity before $\sim 1945$, and subsequently became more saline and brackish in response to gradual increase in sea-level.

3. In the mid-1970s A. "beccarii" may have been mainly influenced by flooding, because $E$. excavatum is absent from the assemblage. However, sea-level rise may also have influenced the increase of $A$. "beccarii".

4. The foraminiferal assemblage is well correlated with changes in COD (Chemical Oxygen Demand), indicating that higher organic contents in the lake are necessary as a food resource.

5. The sea-level rise after the late 1990s is associated with decreased numbers of foraminiferal individuals, implying reduced fertility loadings in the lake waters. However, the mechanisms of this recent sea-level change are not the same as those of earlier events in the 1950-60s and the 1970s, which enhanced foraminiferal productivities.

\section{Acknowledgments}

We thank Mr. H. Fujita (Izumo Construction Company) for the coring, and Dr. H. Takata (Shimane Univ.) for their constructive comments on the earlier draft of this paper. I deeply appreciate the editor, Dr. S. Sato of Tohoku Univ., for improving the manuscript. The Izumo Bureau of Public Works kindly supplied the water depth data for the Sashimi River. This work was supported by Grant-in-Aid for Scientific Research (A) (Ritsuo Nomura, no. 15204046).

\section{References}

Abbene, I.J., Culver, S.J., Corbett, D.R., Buzas, M.A. and Tully, L.S. (2006) Distribution of foraminifera in Pamlico Sound, North Carolina, over the past century. Journal of Foraminiferal Research, 36, 135151.

Alve, E. (1995) Benthic foraminiferal response to estuarine pollution: A review. Journal of Foraminiferal Research, 25, 190-203.

Barmawidjaja, D.M., van der Zwaan, G.J., Jorissen, F. J. and Puskaric, S. (1995) 150 years of eutrophication in the northern Adriatic Sea : Evidence from a benthic foraminiferal record. Marine Geology, 122, 367-384.

Cearreta, A., Irabien, M. J., Leorri, E., Yusta, I., Croudace, I.W. and Cundy, A.B. (2000) Recent anthropogenic impacts on the Bilbao Estuary, northern Spain : Geochemical and microfaunal evidence. Estuarine, Coastal and Shelf Science, 50, 571-592.

Center for Global Environmental Research (2000) Data book of sea-level rise 2000. 128 p, National Institute for Environmental Studies/Environment Agency of Japan (Tsukuba, Japan). (J+E)

Culver, S. J. and Horton, B.P. (2005) Infaunal marsh foraminifera from the outer banks, North Carolina. Journal of Foraminiferal Research, 35, 148-170.

Editorial Committee of the Nature of Lake Jinzai (1995) Nature of Lake Jinzai. 181 p, Tatara Publishing Co. $(\mathrm{J})$

Gooday, A.J. (1993) Deep-sea benthic foraminifera to the deposition of phytodetritus in the deep sea. 
Nature, 332, 70-73.

Hashitani, H., Seike, Y. and Akiba, M. (1995) Water quality of Lake Jinzai. Editorial Committee of the Nature of Lake Jinzai (ed.) Nature of Lake Jinzai : 35-57, Tatara Publishing Co. (J)

Hayward, B.W., Grenfell, H.R. and Scott, D.B. (1999) Tidal range of marsh foraminifera for determining former sea-level heights in New Zealand. New Zealand Journal of Geology and Geophysics, 42, 395413.

Hayward, B.W., Scott, G.H., Grenfell, H.R., Carter, R. and Lipps, J.H. (2004a) Estimation of tidal elevation and salinity histories of sheltered harbours and estuaries using benthic foraminifera. Holocene, 14, 218-232.

Hayward, B.W., Grenfell, H.R., Nicholson, K., Parker, R., Wilmhurst, J., Horrocks, M., Swales, A. and Sabaa, A.T. (2004b) Foraminiferal record of human impact on intertidal estuarine environments in New Zealand's largest city. Marine Micropaleontology, 53, 37-66.

Horton, B.P. and Edwards, R.J. (2006) Quantifying Holocene sea-level change using intertidal foraminifera : Lessons from the British Isles. $97 \mathrm{p}$, Cushman Foundation for Foraminiferal Research, Special Publication, no. 40, Cushman Foundation for Foraminiferal Research.

Igarashi, Y., Otsuji-Hatori, M. and Hirose, K. (1996) Recent deposition of ${ }^{90} \mathrm{Sr}$ and ${ }^{137} \mathrm{Cs}$ observed in Tsukuba. Journal of Environmental Radioactivity, 31, 157169.

IPCC (2007) Summary for Policymakers. Solomon, S., Qin, D., Manning, M., Chen, Z., Marquis, M., Averyt, K.B., Tignor, M. and Miller, H.L. (eds.) Climate Change 2007 : The Physical Science Basis. Contribution of Working Group I to the Fourth Assessment Report of the Intergovernmental Panel on Climate Change : 1-18, Cambridge University Press. http : //www.ipcc.ch/pdf/assessment-report/ar4/ wg1/ar4-wg1-spm.pdf, cited in 2009.

Izumo Bureau of Public Works (2004) Review of the disasters in the basin area of Lake Jinzai. 2, News of Lake Jinzai basin. http : //www.sctc.or.jp/doboku /izumo/topic/topic0411.htm, cited in 2005. (J)

Izumo City Committee (1982) Fresh-water fishery. Izumo City Committee (ed.) 40-years memoirs of Izumo City : 608-610, Izumo City. (J)

Japan Meteorological Agency (2007) http: //www. data.kishou.go.jp/kaiyou/shindan/a_1/sl_trend/ sl_trend.html, cited in 2007. (J)

Japan Meteorological Agency (2009) http://www. data.jma.go.jp/obd/stats/etrn/index.php, cited in 2009. (J)

Kanai, Y. and Ikehara, K. (1995) Sedimentation rates of offshore deposits in the Sea of Japan off Niigata Prefecture, using $\mathrm{Pb}-210$ and $\mathrm{Cs}-137$ radioactivity measurements. Bulletin of the Geological Survey of Japan, 46, 269-282. $(\mathrm{J}+\mathrm{E})$

Kanai, Y., Inouchi, Y., Katayama, H. and Saito, Y.
(1995) Estimation of sedimentation rate at the Lake Suwa in Nagano Prefecture determined by $\mathrm{Pb}-210$ and Cs-137 radioactivities. Bulletin of the Geological Survey of Japan, 46, 225-238. (J+E)

Kano, K., Matsuura, H., Sawada, S. and Takeuchi, K. (1998) Geology of the Iwami-Oda and Oura districts. With geological sheet map at $1: 50,000,118$, Geological Survey of Japan. (J+E)

Kawabe, M. (2001) Interannual variations of sea level at the Nansei Islands and volume transport of the Kuroshio due to wind changes. Journal of Oceanography, 57, 189-205.

Konishi, T., Sakurai, K. and Naito, S. (2004) Long term sea level change around Japan : Review of related research and characteristics of the sea level around Japan. Sokko-Jiho, no. 71, s173-s195. (J)

Koryo Town Committee (1970) Fresh-water fishery. Koryo Town Committee (ed.) Memoirs of Koryotown : 105-106, Koryo Town, Shimane Prefecture. (J)

Koryo Town Committee (2000) Construction of the Sashimi River. Koryo Town Committee (ed.) Memoirs of Koryo-town : 478-486, Koryo Town, Shimane Prefecture. (J)

Krishnaswamy, S., Lal, D., Martin, J. M. and Meybeck, M. (1971) Geochronology of lake sediments. Earth and Planetary Science Letters, 11, 407-414.

Majewski, W. and Zajaczkowski, M. (2007) Benthic foraminifera in Adventfjorden, Svalbard : Last 50 years of local hydrographic changes. Journal of Foraminiferal Research, 37, 107-124.

Müller, P. J. (1977) C/N ratios in Pacific deep sea sediments : Effect of inorganic ammonium and organic nitrogen compounds sorbed by clays. Geochimica et Cosmochimica Acta, 41, 765-776.

Nomura, R. (2003) Assessing the role of artificial vs. natural impacts on brackish lake environments : Foraminiferal evidence from Lake Nakaumi, southwest Japan. Journal of the Geological Society of Japan, 109, 197-214.

Nomura, R., Nemoto, N. and Komura, K. (2006) Environmental changes in brackish lake Obuchi-numa, Aomori Prefecture, northeast Honshu, Japan, with special reference to sea-level variation in the 20th Century. The Quaternary Research (DaiyonkiKenkyu), 45, 347-360.

Nomura, R., Ninagawa, K. and Nishido, H. (2008) Significance of sea-level variations over the last 60 years, indicated by foraminiferal assemblage changes in Kumihama Bay, Kyoto Prefecture, southwest Japan. Journal of Geography, 117, 967-984. (J+E)

Ohga, T. and Kitazato, H. (1997) Seasonal changes in bathyal foraminiferal populations in response to the flux of organic matter (Sagami Bay, Japan). Terra Nova, 9, 33-37.

Oldfield, F. and Appleby, P.G. (1984) Empirical testing of ${ }^{210} \mathrm{~Pb}$ dating models. Haworth, E.Y. and Lund, J.G. (eds.) Lake sediments and environmental history : 93-124, Leicester University Press. 
Patterson, R.T. (1990) Intertidal benthic foraminiferal biofacies on the Fraser River Delta, British Columbia : Modern distribution and paleoecological importance. Micropaleontology, 36, 229-244.

Platon, E., Sen Gupta, B.K., Rabalais, N.N. and Turner, R.E. (2005) Effect of seasonal hypoxia on the benthic foraminiferal community of the Louisiana inner continental shelf: The 20th century record. Marine Micropaleontology, 54, 263-283.

Ruiz, F., Gonzalez-Regalado, M.L., Borrego, J., Abad, M. and Pendon, J.G. (2004) Ostracoda and foraminifera as short-term tracers of environmental changes in very polluted areas: The Odiel Estuary (SW Spain). Environmental Pollution, 129, 49-61.

Sampei, Y. and Matsumoto, E. (2001) C/N ratios in a sediment core from Nakaumi Lagoon, southwest Japan : Usefulness as an organic source indicator. Geochemical Journal, 35, 189-205.

Sawai, Y., Tango, M. and Takayasu, K. (1998) Flood events recognized from lake sediments in Lake Jinzai, Shimane Prefecture, Japan. Laguna, 5, 39-46. $(\mathrm{J}+\mathrm{E})$

Scott, D.B. and Medioli, F.S. (1980) Quantitative studies of marsh foraminifera distribution in Nova Scotia : Implication for sea-level studies. $58 \mathrm{p}$, Cushman Foundation for Foraminiferal Research, Special Publication, no. 17, Cushman Foundation for Foraminiferal Research.

Senjyu, T., Matsuyama, M. and Matsubara, N. (1999) Interannual and decadal sea-level variations along the Japanese coast. Journal of Oceanography, 55, 619-633.

Shimane Prefectural Government (2004) News of rivers and seashore in Shimane Prefecture, June, 2004. http : //www.pref.shimane.lg.jp/kasen/tayori1/ h16-tayori.data/h16-6.pdf, cited in 2005. (J)

Shimane Prefectural Government (2005) Program of water quality testing for public water area and ground water. http : //www.pref.shimane.lg.jp/environment/kankyo/kankyo/mizu/chousa/index. html, cited in 2006. ( J)

Shimane Prefectural Government (2006) A fundamental plan to organize the Jyukken-gawa river system in good condition. http : //www.pref.shimane. jp/section/mizube/library/housin/jikken_houshin. pdf, cited in 2006. (J)

Thomas, E., Gapotchenko, T., Varekamp, J.C., Mecray, E.L. and Buchholtz ten Brink, M.R. (2000) Benthic foraminifera and environmental changes in Long Island Sound. Journal of Coastal Research, 16, 641-
655.

Tsujimoto, A., Nomura, R., Yasuhara, M. and Yoshikawa, S. (2006a) Accelerated eutrophication of coastal waters in Japan : Comparative studies of benthic foraminiferal assemblages during the last 50 years in Osaka Bay, southwestern Japan. Paleontological Research, 10, 141-161.

Tsujimoto, A., Nomura, R., Yasuhara, M., Yamazaki, H. and Yoshikawa, S. (2006b) Impact of eutrophication on shallow marine benthic foraminifers over the last 150 years in Osaka Bay, Japan. Marine Micropalaeontology, 60, 258-268.

Tsujimoto, A., Yasuhara, M., Nomura, R., Yamazaki, H., Sampei, Y., Hirose, K. and Yoshikawa, S. (2008) Development of modern benthic ecosystems in eutrophic coastal oceans: The foraminiferal record over the last 200 years, Osaka Bay, Japan. Marine Micropaleontology, 69, 225-239.

Tyson, R.V. (1995) Sedimentary organic matter : Organic facies and Palynofacies. 615 p, Chapman and Hall.

Van der Zwaan, G. J. (2000) Variation in natural vs. anthropogenic eutrophication of shelf areas in front of major rivers. Martin, R.E. (ed.) Environmental micropaleontology : The application of microfossils to environmental geology : 385-404, Kluwer Academic/Plenum Publishers.

Vance, D. J., Culver, S. J., Corbett, D.R. and Buzas, M.A. (2006) Foraminifera in the Albemarle estuarine system, North Carolina : Distribution and recent environmental change. Journal of Foraminiferal Research, 36, 15-33.

Walling, D.E., He, Q. and Appleby, P.G. (2002) Conversion models for use in soil-erosion, soil-redistribution and sedimentation investigations. Zapata, F. (ed.) Handbook for the assessment of soil erosion and sedimentation using environmental radionuclides : 111-164, Kluwer Academic Publishers.

Williams, H.F.L. (1994) Intertidal benthic foraminiferal biofacies on the central Gulf Coast of Texas : Modern distribution and application to sea level reconstruction. Micropaleontology, 40, 169-183.

Yamada, K., Takata, T. and Takayasu, K. (2004) Holocene paleoenvironmental changes recorded in lacustrine sediments of Lake Jinzai, Shimane Prefecture, western Japan. Laguna, 11, 135-145. (J+E)

$(\mathrm{J})$ in Japanese, $(\mathrm{J}+\mathrm{E})$ in Japanese with English abstract 


\title{
島根県神西湖（汽水湖）における過去 60 年間の洪水, 人間活動および海面水位変動に対する有孔虫の応答
}

\author{
野村 律 夫*1,a・ローザー・バリー*2
}

\begin{abstract}
〔要旨〕
島根県北東部にある神西湖の有孔虫群集について, 過 去 60 年間の海面水位変動之洪水による影響について検 討を行った. 日本の沿岸で認められている 1950 年代と 1970 年代の中頃の海面水位の上昇期には, 汽水性の $A m$ monia "beccarii" の産出個体数が増えていた. しかし, 1990 年代以降の海面水位の上昇とは調和的な増加はみ られなかった。 1980 年代以降の COD (化学的酸素要求 量)の経年変動と比較すると, 有孔虫の産出はよく似た

ている.

また，洪水事件に対して，(1) A. “beccarii”が増加した あとでElphidium excavatum が増える, (2) A. "beccarii” のみ増える，（3）ともに増加する, の 3 つのパターンが 確認された。 洪水堆積物には有機物量の付加が認められ ないが, 全体としては個体数の増加がみられる。このこ とから, 有孔虫は洪水によって生産性を高めていること が明らかとなった。
\end{abstract} 変化を示すことから, 湖内の有機物量が規制要因になっ

キーワード : 海面水位変動, 洪水, 人間活動, 有孔虫, 20 世紀, 神西湖

*1 島根大学教育学部地学研究・汽水域研究センター $\overline{\mathbf{T}} 690$-8504 松江市西川津町 1060 .

*2 島根大学総合理工学部地球資源学科 =690-8504 松江市西川津町 1060.

*a Corresponding author : nomura@edu.shimane-u.ac.jp 